\title{
Effects of prepartal oronasal administration of lipopolysaccharide on milk composition and productivity of transition Holstein dairy cows
}

\author{
Summera Iqbal ${ }^{1}$, Qendrim Zebeli ${ }^{2}$, Dominik A. Mansmann ${ }^{1}$, Suzanna M. Dunn ${ }^{1}$, \\ Burim N. Ametaj ${ }^{1 *}$ \\ ${ }^{1}$ Department of Agricultural, Food and Nutritional Science, University of Alberta, Edmonton, Canada; \\ *Corresponding Author: burim.ametaj@,ualberta.ca \\ ${ }^{2}$ Institute of Animal Nutrition and Functional Plant Compounds, Department for Farm Animals and Veterinary Public Health, Vet- \\ meduni Vienna, Vienna, Austria
}

Received 1 June 2013; revised 25 June 2013; accepted 2 July 2013

Copyright (C) 2013 Summera Iqbal et al. This is an open access article distributed under the Creative Commons Attribution License, which permits unrestricted use, distribution, and reproduction in any medium, provided the original work is properly cited.

\section{ABSTRACT}

The aim of this study was to evaluate the effects of repeated oronasal administration of lipopolysaccharide (LPS) on milk composition and the overall productive performance of dairy cows. One hundred pregnant Holstein dairy cows were randomly assigned to two treatment groups $(n=$ 50). 30 cows out of 100 were selected for intensive sampling $(n=15)$ starting at $28 \mathrm{~d}$ before parturition. Cows were administered orally and nasally with 2 and $1 \mathrm{~mL}$ of saline solution, respectively (control), or saline solution containing 3 doses of LPS from Escherichia coli 0111:B4 as follows: 1) $0.01 \mu \mathrm{g} / \mathrm{kg}$ body weight (BW) on d $-28,2) 0.05 \mu \mathrm{g} / \mathrm{kg}$ BW on d -25 and -21 , and 3) $0.1 \mu \mathrm{g} / \mathrm{kg} \mathrm{BW}$ on $\mathrm{d}-18$ and -14 . Daily feed intake and milk production were recorded for each cow during the first $28 \mathrm{~d}$ postpartum. Milk samples were obtained once per week and analyzed for various milk components. Overall, results indicated that treatment did not affect feed intake, milk yield, milk efficiency, fat content, fat yield, protein content, protein yield, lactose content, lactose yield, milk urea nitrogen (MUN), total solid contents, fat-corrected milk (FCM), and energy-corrected milk (ECM; $P$ > 0.05). However, milk somatic cell count (SCC) tended to be lower in the treated cows $(P<0.10)$. Treated primiparous cows showed tendencies for better milk efficiency $(P<0.10)$, milk-fat content $(P=0.09)$, and total solid contents $(P=$ $0.06)$. There was a treatment by week interaction for milk energy $(P=0.03)$, and tendencies for FCM, ECM, lactose content, and milk efficiency
$(P<0.10)$ with greater values in the treated primiparous animals. Altogether, results of this study showed that oronasal LPS challenges slightly modulated milk composition of periparturient dairy cows.

Keywords: Lipopolysaccharide; Oronasal; Milk Composition; Dairy Cows

\section{INTRODUCTION}

The normal function of the bovine mammary gland is disrupted during microbial infections and by the harmful toxins that they release early post-partum [1]. Among the various harmful bacterial toxins lipopolysaccharide (LPS), a cell wall component of all Gram-negative bacteria (GNB), commonly known as endotoxin, has received much attention $[1,2]$. The potential source for LPS could be the mammary gland itself following GN infection, which caused pathological changes in the mammary tissue, and developed local inflammatory conditions $[3,4]$. Lipopolysaccharide also might originate from other sources such as gastrointestinal tract and uterus [3]. During the transition period, rumen carries high loads of free LPS especially when cows are switched from the dry off period diets low in grain to high-grain diets early postpartum. The latter diets are known to cause sudden depression of ruminal $\mathrm{pH}$ with the onset of subacute ruminal acidosis and consequently disrupting the balance of multi-species microbiota with a major shift towards GNB $[5,6]$. It is also evident that rumen LPS translocates into the bloodstream and further into the mammary gland where it suppresses the functions of the mammary epithelial cells (MEC) [6,7]. 
A recent study from our group evidenced a strong association between rumen free LPS with systemic inflammatory responses and milk-fat depression in lactating dairy cows [2]. This indicates that the supply of nutrients for synthesis of milk components is hampered following endotoxin exposure. Several previous studies showed that endotoxin decreases de novo fat synthesis of the mammary gland by suppressing the activity of fatty acid (FA) synthetase and acetyl-CoA carboxylase [8,9] as well as down-regulating lipoprotein lipase (LPL), which lowers the uptake of FA for milk fat synthesis [10]. In addition, endotoxin causes various changes in other milk components and suppresses milk yield [11]. For example, intramammary injection of endotoxin induces a 100-fold increase in milk SCC and a 50\% elevation in the concentration of protein content [12].

Despite major progress in understanding the role of LPS in the etiopathology of periparturient diseases in transition dairy cows there is a lack of effective prophylactic strategies against its translocation into the host systemic circulation. Various parenteral vaccines have been designed to combat GN bacterial infections, especially those caused by E. coli, such as J5 core antigen against mastitis [13]. However, in the case of parenteral vaccines, immunoglobulin ( $\mathrm{Ig}) \mathrm{G}$ and IgM humoral responses are induced, which work by attacking intruding bacteria. Mucosal vaccines have received much attention during recent years, and it is well known that by priming the immune response via one mucosal route generally stimulates production of secretory $\operatorname{IgA}(\mathrm{sIgA})$ at various adjacent mucosal layers [14]. Several recent studies have shown that repeated intra-mammary infusion of sublethal doses of $E$. coli LPS mimics intra-mammary inflammation caused by GN infection [15-18], without having any deleterious effects on milk production in dairy cows [19]. Recent data from our group indicated increased anti-LPS IgM antibodies and better overall immune and metabolic health status in dairy cows treated orally with LPS [20]. To our best knowledge, the effects of oronasal administration of LPS have not been studied in transition dairy cows yet. We hypothesized that repeated oronasal administration of increasing doses of LPS in prepartum dairy cows might affect milk production and composition as well as the number of SCC in early lactating dairy cows. Therefore the objectives of this study were to treat cows oronasally with LPS for a period of 3 weeks starting at 4 weeks before parturition and monitor milk production, its composition, and the SCC in transition dairy cows.

\section{MATERIALS AND METHODS}

\subsection{Animals and Treatments}

One hundred pregnant Holstein dairy cows were randomly assigned to two treatment groups $(n=50$ per group) according to parity, milk production, BCS, and disease susceptibility from previous year. Thirty cows out of 100 (i.e., 10 primiparous with average weight of $600 \mathrm{~kg}$ and 20 multiparous cows with average weight of $720 \mathrm{~kg})$ were assigned to intensive sampling $(\mathrm{n}=15 \mathrm{per}$ group) starting at $-28 \mathrm{~d}$ before the expected day of parturition.

Fifty cows in the treatment group were orally and nasally administered 2 and $1 \mathrm{~mL}$ of sterile saline solution, respectively, containing 3 increasing doses of LPS from E. coli 0111:B4 supplied by Sigma-Aldrich Canada Ltd. (Oakville, ON, Canada) as follows: 1) $0.01 \mu \mathrm{g} / \mathrm{kg}$ body weight $(\mathrm{BW})$ once per week on $\mathrm{d}-28$ before parturition, 2) $0.05 \mu \mathrm{g} / \mathrm{kg} \mathrm{BW}$ twice per week on $\mathrm{d}-25$ and -21 before parturition, and 3) $0.1 \mu \mathrm{g} / \mathrm{kg} \mathrm{BW}$ twice per week on $\mathrm{d}-18$ and -14 before the expected day of parturition. Doses of LPS used were determined from a previous investigation conducted by our research group and based on the clinical and pathological responses to those doses in order to prevent lethal endotoxemia and induction of a refractory state against endotoxin [20]. For preparation of the LPS doses, initial crystalline $E$. coli LPS containing $10 \mathrm{mg}$ of purified LPS was dissolved in $10 \mathrm{~mL}$ of doubly distilled water (as suggested by Sigma-Aldrich Canada Ltd., Oakville, ON, Canada), and stored in the refrigerator at $4^{\circ} \mathrm{C}$ until the time of administration. For oral and nasal administrations of LPS, the daily dose was dissolved in 2 and $1 \mathrm{~mL}$ of sterile saline solution, and then introduced into the oral and nasal cavity of the cows, respectively, using a disposable $5 \mathrm{~mL}$ syringe (Becton, Dickinson and Company, BD, Franklin Lakes, NJ). Similarly, the same amount of carrier (i.e., 2 and $1 \mathrm{~mL}$ of sterile saline supplied by Sigma-Aldrich Canada Ltd., Oakville, ON, Canada) was administered orally and nasally to all cows in the control group, on the same days as for the LPS treatments. All experimental procedures were approved by the University of Alberta Animal Care and Use Committee for Livestock and animals were cared for in accordance with the guidelines of the Canadian Council on Animal Care [21].

The experiment started $28 \mathrm{~d}$ before the expected day of parturition and lasted until $28 \mathrm{~d}$ after parturition. Cows were housed in tie stalls and transferred to the maternity pens shortly before parturition and returned to their stalls on the next day of calving. Cows were having free access to water throughout the experiment. The daily ration was offered as total mixed ration (TMR) to all animals in their stalls at 0800 for ad-libitum intake to allow approximately $10 \%$ feed refusals throughout the experiment. The composition of the TMR was based on the close up dry period diet, and started being fed to all cows at $21 \mathrm{~d}$ before the expected day of parturition. Then, all cows were switched to the lactation diet gradually during the first $7 \mathrm{~d}$ after parturition. All diets were formulated to meet or exceed the nutrient requirements of dry and early 
lactating cows as per NRC [22] guidelines. Ingredients and chemical composition of the diets for the dry and early lactating cows are presented in Tables $\mathbf{1}$ and 2, res-

Table 1. Ingredients and chemical composition of the diet for dry cows.

\begin{tabular}{cc}
\hline Ingredients, \% of DM & Prepartum diet \\
\hline Alfalfa hay & 10.0 \\
Barley silage & 63.0 \\
Alfalfa silage & 00.0 \\
CUD $^{1}$ grain & 27.0 \\
Nutrient composition of cud grain & \\
(dietary supplement) & \\
\% amount in 100 kg mix & 55.0 \\
Barley grain, rolled & 7.5 \\
Canola meal & 6.2 \\
Dairy dry cow micro-premix & 8.7 \\
Limestone & 15.7 \\
Animate & 0.9 \\
Molasses & 4.1 \\
Canola oil & 1.7 \\
Yeast &
\end{tabular}

${ }^{1} \mathrm{CUD}=$ giving more mineral especially $\mathrm{Ca}$ to avoid milk fever in early lactating cows.

Table 2. Ingredients and chemical composition of the diet for early lactating cows.

\begin{tabular}{|c|c|}
\hline Ingredients, \% of DM & Early lactation diet \\
\hline Alfalfa hay & 10.0 \\
\hline Barley silage & 40.8 \\
\hline Dairy supplement & 49.2 \\
\hline \multicolumn{2}{|c|}{$\begin{array}{l}\text { Nutrient composition of dairy supplement, } \\
\% \text { amount in } 100 \mathrm{~kg} \text { mix }\end{array}$} \\
\hline ADE Vit Pak-30 Natural E & 0.056 \\
\hline Ruminant TM Pak & 0.1025 \\
\hline \multicolumn{2}{|l|}{ Selenium 1000 mg/kg (UNscr FineCr) } \\
\hline Custom TM Complex pmx & 0.065 \\
\hline Di-calcium phosphate $21 \%$ & 0.060 \\
\hline Co-opalantic Corn Dist & 1.25 \\
\hline Corn ground & $\begin{array}{l}10.0 \\
25.0\end{array}$ \\
\hline Corn rolled & 30.105 \\
\hline Vit D-10,000 KIU $/ \mathrm{kg}$ & 0.015 \\
\hline Diamond V XPC & 0.14 \\
\hline Magalac/Enertia & 1.00 \\
\hline & 2.00 \\
\hline Fermenten & 1.50 \\
\hline Limestone & 0.37 \\
\hline \multicolumn{2}{|l|}{ Mag Ox-56\% } \\
\hline Canola meal & 15.5 \\
\hline Hi bypass soy (Amino plus) & 2.75 \\
\hline Soy bean meal- $47.5 \%$ & 6.50 \\
\hline Sodium bicarbonate & 1.00 \\
\hline Salt & 0.113 \\
\hline Pork-Tallow & $\begin{array}{c}2.45 \\
0.007\end{array}$ \\
\hline Biotin 2\%-Rovimix H-2 & 0.015 \\
\hline ADM Vit E 405 Vegetable sourc & \\
\hline
\end{tabular}

pectively.

\subsection{Feed Intake and Milk Composition}

Feed intake and milk production were recorded daily during the 4 week before and 4 week after parturition. Feed intake was calculated for each individual cow by the difference between the total daily feed given with that of the feed refusals of the next morning. Milk samples were collected once per week at 0500 and 1500 and analyses were done for milk fat, crude protein $(\mathrm{CP})$, milk urea nitrogen (MUN), somatic cell count (SCC), and lactose content by mid-infrared spectroscopy (MilkoScan 605; A/S N Foss Electric, Hillerød, Denmark) at Central Milk Testing Laboratory in Edmonton, Alberta. Daily milk energy output was calculated from measured milk yield and concentrations of milk fat, $\mathrm{CP}$, and lactose according to the NRC (2001) equation: NEL (Mcal $/ \mathrm{kg}$ milk $)=0.0929 *$ fat $\%+0.0547 *$ protein $\%+0.0395 *$ lactose $\%$. The net energy required for lactation (NEL) intake was estimated from measured DMI and NEL content of the diets, whereby the latter was determined as the sum of NEL content of individual feeds in a feeding level at 3 times maintenance (NRC, 2001). The ratio of NEL milk output: NEL intake was calculated to evaluate the effect of treatment on milk energy efficiency.

\subsection{Statistical Analyses}

Data were analyzed using the MIXED procedure of SAS (SAS Institute Inc., Cary, NC, USA Version 9.1.3) as describe by the following model:

$$
\begin{aligned}
Y i j k l= & \mu+\gamma i+\alpha j+\beta k+\kappa l+(\alpha \beta) j k \\
& +(\alpha \kappa) j l+(\beta \kappa) k l+\varepsilon i j k l
\end{aligned}
$$

where Yijkl is the observation for dependant variables, $\mu$ is the population mean, $\gamma i$ is the independent parameter for animal $i, \alpha j$ is a population parameter corresponding to treatment $j, \beta k$ is the fixed effect of measurement week (relative to each LPS challenge) $k, k l$ is the fixed effect of parity $1,(\alpha \beta) j k$ is the effect of treatment by measurement week interaction, $(\alpha \kappa) j l$ is the effect of treatment by parity interaction, $(\beta \kappa) k l$ is the effect of measurement week by parity interaction, and $\varepsilon i j k l$ is the residual error. Data are shown as least-squares means (LSM) and standard error of the mean (SEM). Multiple comparisons of LSM were conducted by probability difference (PDIFF) option of SAS. Measurements on the same animal were considered as repeated measures. The covariance structure of the repeated measurements for each variable was modeled separately according to the lowest values of fit statistics based on the Bayesian information criteria (BIC). The significance limit was declared at $\mathrm{P}<0.05$, whereas a biologically relevant tendency was declared at $0.05<\mathrm{P}<0.10$. 


\section{RESULTS}

\subsection{Feed Intake and Milk Yield}

Overall results regarding feed intake are given in Figure 1(a). Data showed that treatment did not alter this variable between the treated and control cows $(P>0.05)$. However, the factor measurement week showed an influence on feed intake $(\mathrm{P}<0.01)$ with numerical lower values in control cows after parturition. There was no treatment by week interaction regarding feed intake $(\mathrm{P}>$ $0.05)$.

No differences between the control and treated cows were obtained for milk yield in the overall analysis of data $(P>0.05$; Figure 1(b)), although an effect of week was evidenced by ANOVA $(\mathrm{P}=0.01)$. Milk yield declined numerically in the saline treated cows after parturition and returned to the level of the treated cows afterwards at week 3 and then slightly increased at week 4 . In addition, there was no treatment by week interaction re-

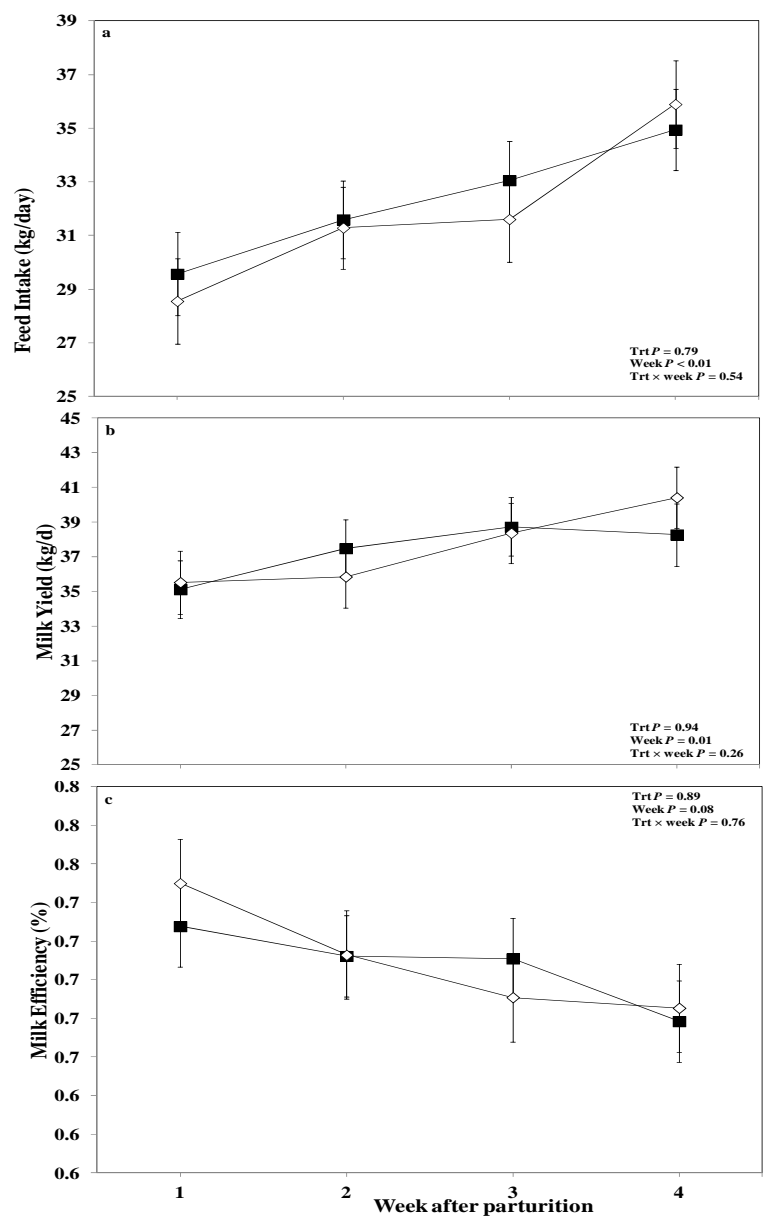

Figure 1. Weekly variations in milk (a) feed intake, (b) milk yield, and (c) milk efficiency of multiparous and primiparous Holstein cows challenged with oronasal treatment of LPS (Trt; 口) or saline (Control; $\diamond)(\mathrm{LSM} \pm \mathrm{SEM} ; \mathrm{n}=15$; Trt $=$ effect of treatment; Week $=$ effect of sampling week, Trt $\times$ week $=$ effect of treatment by sampling week). garding milk yield in this study $(\mathrm{P}>0.05)$. Overall results indicated no differences regarding milk efficiency between the control and treated animals $(P>0.05$; Figure 1(c)). Also, there were no week effect or interaction between treatment and week in this study $(P>0.05)$.

Data evidenced an effect of parity regarding milk efficiency. Treated primiparous cows showed a tendency for better milk efficiency than their respective control group animals, indicating that they produced more milk relative to their feed intake ( $\mathrm{P}<0.10$; Table 3). Multiple comparisons of data indicated that this effect was more pronounced at week 1 following parturition $(\mathrm{P}=0.01)$ with greater values in primiparous treated cows than the control ones. The factor week also had an effect for this variable $(\mathrm{P}=0.02)$; and there was a tendency for treatment by week interaction for milk efficiency between the treated and control heifers $(\mathrm{P}<0.10)$. A treatment by week interaction was also obtained for milk energy in primiparous cows $(\mathrm{P}=0.03$; Table 3$)$, and multiple comparison test indicated that this variable tended to be greater in oronasally LPS challenged heifers at week 3 than their respective control animals $(P<0.10)$. There was no effect of measurement week or treatment regarding milk energy for this group of cows $(\mathrm{P}>0.05)$.

\subsection{Milk Composition}

Overall results obtained with regards to milk fat variables are shown in Figure 2. Milk-fat content was not

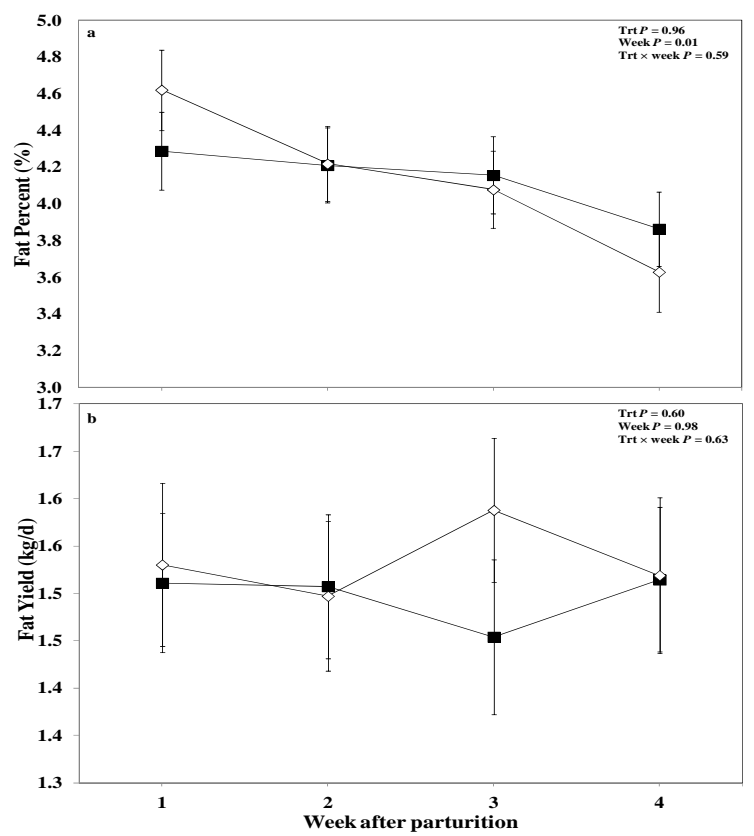

Figure 2. Weekly variations in milk (a) fat content, and (b) fat yield primiparous of multiparous and primiparous Holstein cows challenged with oro-nasal treatment of LPS (Trt; $\boldsymbol{\square})$ or saline (Control; $\diamond)(\mathrm{LSM} \pm \mathrm{SEM} ; \mathrm{n}=15$; Trt $=$ effect of treatment; Week = effect of sampling week, Trt $\times$ week $=$ effect of treatment by sampling week). 
Table 3. Data of milk composition and production efficiency of lactating primiparous cows administered orally with saline (CTR) or saline containing increasing doses of LPS (Trt).

\begin{tabular}{|c|c|c|c|c|c|c|}
\hline \multirow{3}{*}{ Variable } & \multirow{2}{*}{\multicolumn{3}{|c|}{$\begin{array}{l}\text { Treatment groups }^{1} \\
\text { Primiparous cows }\end{array}$}} & \multirow{2}{*}{\multicolumn{3}{|c|}{ Overall Effect $^{2}$, P-value }} \\
\hline & & & & & & \\
\hline & Trt & CTR & SEM & Trt & wk & Trt $\times$ wk \\
\hline $\mathrm{FCM}^{3}$ & 36.3 & 36.2 & 1.56 & 0.97 & 0.87 & $<0.10$ \\
\hline $\mathrm{ECM}^{4}$ & 35.2 & 35.0 & 1.39 & 0.92 & 0.84 & 0.08 \\
\hline Fat content, $\%$ & 4.54 & 4.20 & 0.13 & 0.09 & 0.02 & 0.33 \\
\hline Lactose content, \% & 4.52 & 4.49 & 0.04 & 0.68 & 0.70 & $<0.10$ \\
\hline Total solids, $\%$ & 13.1 & 12.7 & 0.16 & 0.06 & 0.02 & 0.50 \\
\hline Milk efficiency & 1.45 & 1.13 & 0.14 & $<0.10$ & 0.02 & $<0.10$ \\
\hline Milk energy ${ }^{5}, \mathrm{Mcal} / \mathrm{d}$ & 23.1 & 22.9 & 1.02 & 0.87 & 0.72 & 0.03 \\
\hline
\end{tabular}

${ }^{1} \mathrm{CTR}=$ cows administered orally with saline solution; Trt = cows administered orally with increasing doses of lipopolysaccharide. ${ }^{2}$ Effect of treatment (Trt), measurement week (wk), and treatment by week interaction (Trt $\times$ wk). ${ }^{3} \mathrm{FCM}=$ Milk amount $(\mathrm{kg}) *(0.4255+16.425 * 0$ fat $/ 100)$. ${ }^{4} \mathrm{ECM}=\mathrm{Milk}$ amount $(\mathrm{kg}) *(0.327+7.2 * \%$ protein $/ 100+12.96 * \%$ fat $/ 100) .{ }^{5}$ Milk energy $(\mathrm{Mcal} / \mathrm{kg}$ milk $)=0.0929 * \%$ fat $+0.0547 * \% \mathrm{CP}+0.0359 * \%$ lactose.

affected by treatment or treatment by week interaction between the treated and control cows $(\mathrm{P}>0.05)$. However, a week effect was evidenced for milk-fat content $(\mathrm{P}$ $=0.01)$ with this variable showing numerically lower concentrations on week 1 after parturition in oronasal LPS treated cows, which then reached the level of control cows on week 2 , and staying higher for the remainder of the experiment in this group.

Interestingly, in this dataset, the effect of the parity on milk-fat content was found to be one of the most important factors, and milk-fat content tended to be higher in oronasally treated primiparous cows compared to saline treated heifers $(\mathrm{P}=0.09$; Table 3$)$. This effect was more pronounced at week 3 post calving with higher values in the treated heifers $(P=0.02)$. Also measurement week showed an effect $(\mathrm{P}=0.02)$; however, no treatment by week interaction was obtained for this variable $(\mathrm{P}>$ $0.05)$.

Overall ANOVA indicated no differences between control and treated cows for milk fat yield $(\mathrm{P}>0.05$; Figure 2(b)). Furthermore, factor of measurement week alone and treatment by week interaction was not evident regarding milk fat yield in the current study $(\mathrm{P}>0.05)$.

Overall mean results of the ANOVA for FCM (Figure 3(a)), and ECM (Figure 3(b)) revealed that the factor treatment did not show any effect $(\mathrm{P}>0.05)$. There was no effect of sampling week $(\mathrm{P}>0.05)$, and no treatment by week interaction for these variables $(\mathrm{P}>0.05)$. There was a tendency for a treatment by week interaction in the treated primiparous cows for FCM $(\mathrm{P}<0.10$; Table 3) and ECM $(\mathrm{P}=0.08$; Table 3$)$. The multiple comparison analysis indicated a tendency for greater values for FCM $(\mathrm{P}<0.10)$ and ECM $(\mathrm{P}<0.10)$ in the treated heifers at week 3 following parturition. However, the factor measurement week or treatment alone did not show any effect for these cows compared to their respective control group animals ( $\mathrm{P}>0.05$; Table 3$)$.

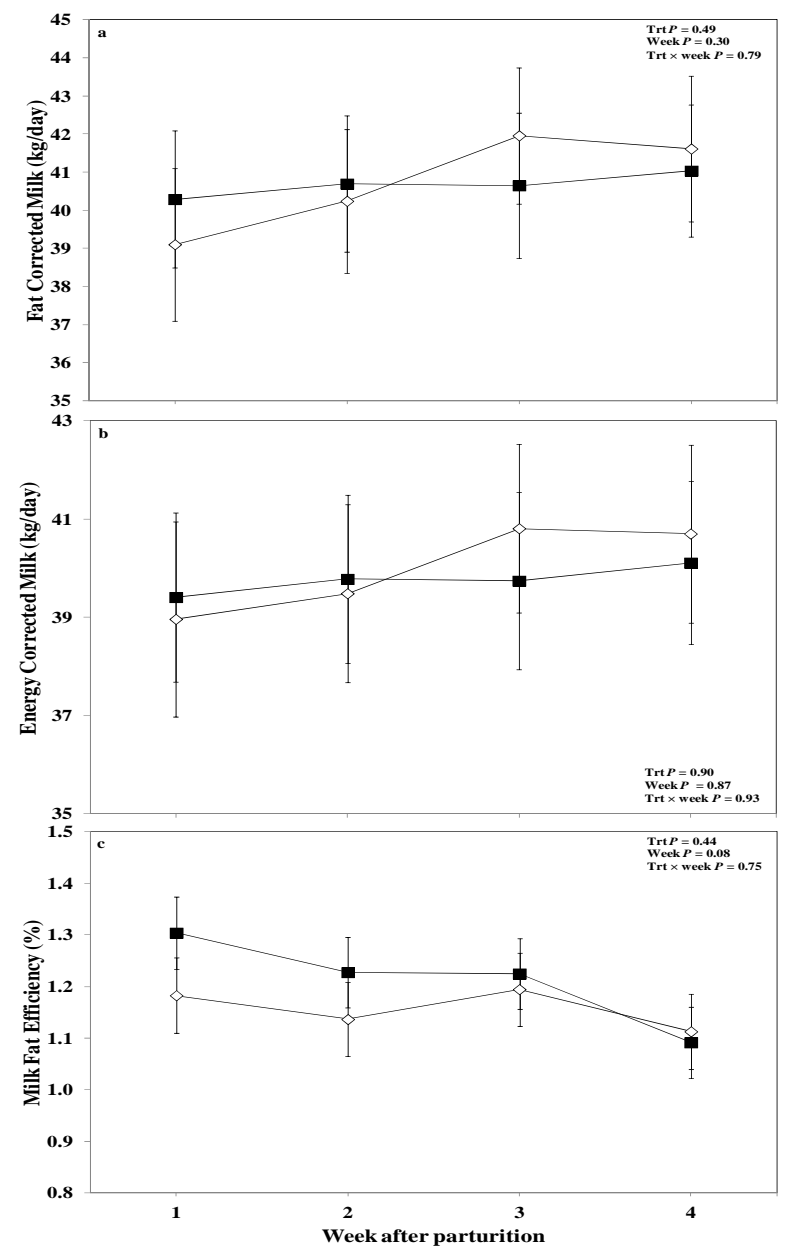

Figure 3. Weekly variations in milk (a) fat corrected milk, (b) energy corrected milk, and (c) milk fat efficiency of multiparous and primiparous Holstein cows challenged with oronasal treatment of LPS (Trt; $\mathbf{\square})$ or saline (Control; $\diamond)(\mathrm{LSM} \pm$ SEM; $\mathrm{n}=15$; Trt = effect of treatment; Week = effect of sampling week, Trt $\times$ week $=$ effect of treatment by sampling week). 
Milk-fat efficiency (MFE) was not different among the control and treated cows in the overall results $(\mathrm{P}>0.05$; Figure 3(c)). There was a tendency for a week effect $(\mathrm{P}$ $=0.08)$, with this variable showing peak values 1 week after parturition in oronasally LPS administered group, slightly decreasing, and staying higher in those cows until week 3 postpartum, decreasing again to the level of control cows at week 4 postpartum. No treatment by week interaction was obtained for MFE in this dataset $(\mathrm{P}$ $>0.05)$.

The overall analysis showed that protein content was not affected by oronasal LPS, or the interaction of treatment by week $(\mathrm{P}>0.05$; Figure 4(a)). An effect of factor week was obtained for this variable $(\mathrm{P}<0.01)$, with lower values in the treated cows at week 1 after parturition, which started to increase at the second week until week 3 , and returned to the level of control cows at week 4.

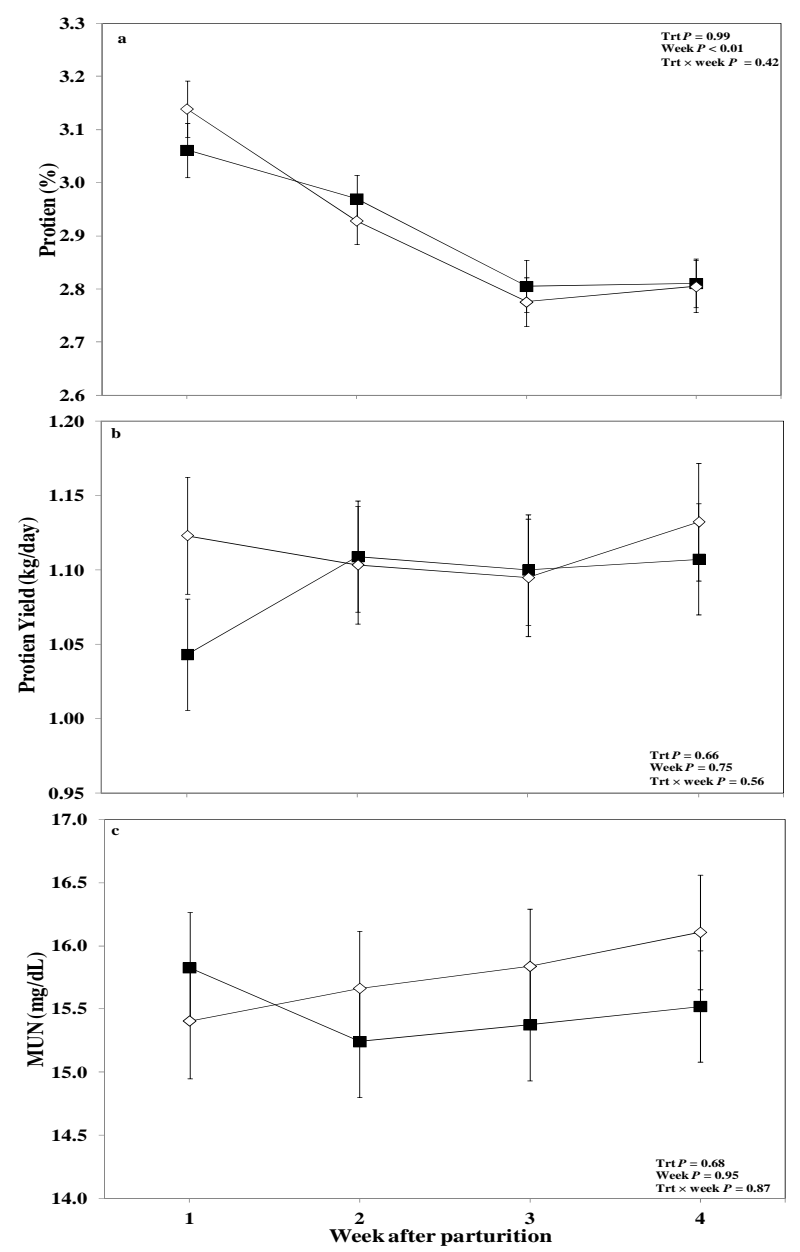

Figure 4. Weekly variations in milk (a) protein content; (b) protein yield; and (b) milk urea nitrogen of multiparous and primiparous Holstein cows challenged with oronasal treatment of LPS (Trt; $\mathbf{\square})$ or saline (Control; $\diamond)(\mathrm{LSM} \pm \mathrm{SEM} ; \mathrm{n}=15$; Trt = effect of treatment; Week = effect of sampling week, Trt $\times$ week $=$ effect of treatment by sampling week).
Results obtained from the overall ANOVA, regarding milk protein yield, indicated no effect of oronasal LPS challenge and sampling week relative to LPS administration or the interaction between these two for this variable (P $>0.05$; Figure 4(b)). Overall dataset also showed no effect of oronasal administration of LPS on MUN (P > 0.05; Figure 4(c)). Furthermore, the factor week of measurement did not influence MUN ( $>>0.05)$, and also there was no treatment by week interaction regarding this variable in this study $(\mathrm{P}>0.05)$.

Milk lactose content and yield overall were not affected by oronasal LPS challenge ( $P>0.05$; Figures 5(a) and (b)), or the interaction of treatment and measurement week $(\mathrm{P}>0.05)$. Also, analysis of the overall data did not reveal any effect of week for milk lactose content $(\mathrm{P}>$ 0.05; Figure 5(b)), although it reached the point of significance for milk lactose yield ( $\mathrm{P}<0.01$; Figure 5(a)). Mean lactose content, by parity category is shown in Table 3, and it revealed a tendency for treatment by week interaction for heifers $(\mathrm{P}<0.10)$, with a tendency

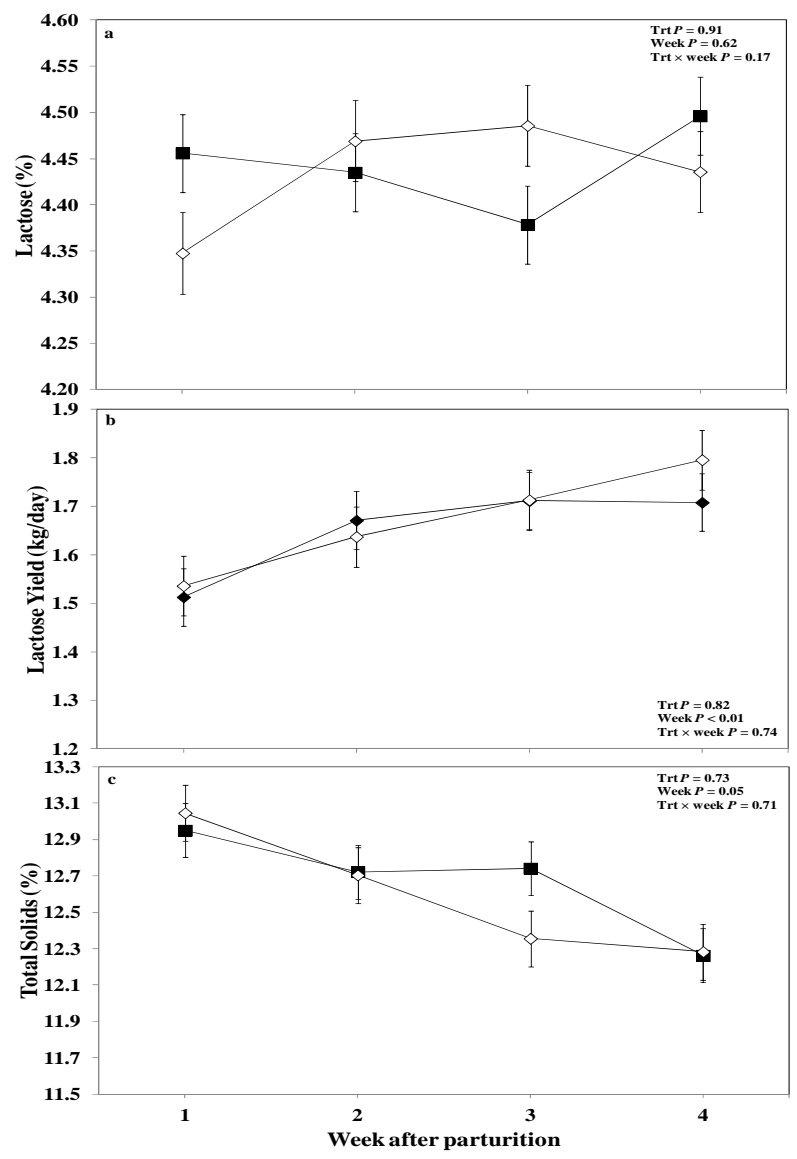

Figure 5. Weekly variations in milk (a) lactose content; (b) lactose yield; and (b) total solids content of multiparous and primiparous Holstein cows challenged with oronasal treatment of LPS (Trt; $\mathbf{\square})$ or saline (Control; $\diamond)(\mathrm{LSM} \pm \mathrm{SEM}$; $\mathrm{n}=15$; Trt $=$ effect of treatment; Week = effect of sampling week, Trt $\times$ week $=$ effect of treatment by sampling week). 
for higher values in the treated primiparous cows at week 1 immediately after calving then their control gro up $(\mathrm{P}=$ $0.08)$.

No effect of treatment or interaction between treatment and week was evidenced for total solid contents of the milk as indicated from the overall means of ANOVA in the current study ( $\mathrm{P}>0.05$; Figure 5(c)); although there was an effect of measurement week alone regarding this variable $(\mathrm{P}=0.05)$.

The total solid contents, categorized by parity are given in Table 3. Results showed a tendency for greater values in the treated primiparous cows than their control counterparts $(P=0.06)$. Furthermore, heifers showed only an influence of measurement week $(\mathrm{P}=0.02)$, with no interaction between treatment and week for this variable $(\mathrm{P}>0.05)$.

Interestingly, statistical processing of the overall data regarding milk SCC revealed that LPS challenge tended to effect this variable and the values started to decrease in the treated cows from the week immediately after parturition till the end of the experiment $(\mathrm{P}<0.10$; Figure 6). No week effect or treatment by week interaction was evident for milk SCC $(\mathrm{P}>0.05)$.

\section{DISCUSSION}

This study was undertaken to evaluate whether repeated oronasal administration of LPS in prepartum dairy cows would be able to modulate the profile of milk components and milk SCC. Indeed, an interesting finding of the present study was a tendency for lower milk SCC in the cows administered oronasally with LPS. It is evident that GNB invasion and the LPS shedding due to the breakdown of the infectious microbes, especially Escherichia coli spp, are often the cause of mammary gland inflammation [23-25]. Several earlier studies indicated that the mammary gland of cows is highly susceptible to

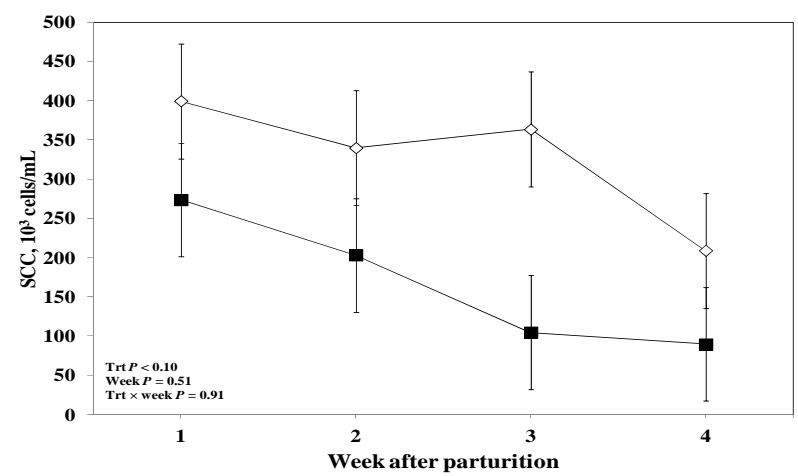

Figure 6. Weekly variations in milk somatic cell count of multiparous and primiparous Holstein cows challenged with oro-nasal treatment of LPS (Trt; $\mathbf{\square})$ or saline (Control; $\diamond)$ $(\mathrm{LSM} \pm \mathrm{SEM} ; \mathrm{n}=15 ;$ Trt $=$ effect of treatment; Week $=$ effect of sampling week, Trt $\times$ week $=$ effect of treatment by sampling week). very low doses of LPS injection, resulting in marked influx of immune cells (especially neutrophils), reflected as high SCC in the milk [26-28]. In a more recent study Lehtolainen et al. [29] reconfirmed that intramammary challenge with LPS results in a marked increase in SCC in early lactation cows. More interestingly, cows inoculated with enterotoxigenic $E$. coli vaccine, followed by intramammary infusion with LPS 3 weeks later, had lower SCC due to suppression of innate immune factors in the milk and production of specific antibodies against the vaccine [30].

The tendency for lower SCC in the treated cows in the present study suggests that oronasal administration of LPS has induced the humoral immunity which lowered proinflammatory mediators and prevented subsequent translocation of large amounts of LPS. This hypothesis is supported by our finding that has been reported in a companion article that oral LPS administration enhanced the overall salivary $\operatorname{IgA}$ secretion [unpublished data]. Determination IgG concentration in the milk, might be a valuable indicator whether LPS treatment improved humoral immune responses in the mammary gland.

Another result of this investigation was a tendency for greater milk fat content and a treatment by week interaction for FCM with greater values in week 3 in the treated primiparous cows. Lipopolysaccharide has been shown to directly suppress key enzymes for the de-novo milkfat synthesis like fatty acid synthetase and acetyl-CoA carboxylase $[8,9]$. In addition, LPS has been shown to inhibit the activity of LPL, the key enzyme for incurporation of fatty acids into the milk fat [31]. Moreover, Shuster et al. [11] found a decline in milk-fat content following intra-mammary infusion with LPS. A recent investigation by Zebeli and Ametaj [2] suggested that feeding dairy cows high-grain diets around parturition triggers an inflammatory response with enhanced C-reactive protein (CRP), which was negatively correlated with milk-fat content, milk-fat yield, and 3.5\% FCM. The authors suggested that CRP inhibits interaction of LPL with apoC-II and as a result lowers the uptake of FA from the mammary gland. The reason why the treatment affected only primiparous and not multiparous animals is not clear at present.

A tendency for better milk efficiency and greater milk energy in primiparous cows also was obtained in this study. Zebeli and Ametaj [2] reported a strong negative correlation between rumen free LPS with MEE in dairy cows. Better MEE also was reported in cows fed diets treated with lactic acid and heat that lowered the amount of LPS in the rumen fluid [32]. Shuster et al. [11] demonstrated reduced lactational performance in dairy cows administered intravenously with LPS.

The relationship between endotoxin and low milk synthetic capacity is explained by the fact that endotoxin 
in the mammary gland influences the metabolism of this tissue by eliciting local immune responses, and directing more nutrients to support immune reactions instead of being consumed as precursors for milk components. On the other hand, activated immune cells in the mammary gland produce large quantities of antibacterial molecules like reactive oxygen species that have been associated with tissue damage. Furthermore, endotoxin exerts a direct harmful effect on MEC by down-regulating their functional and proliferation capacities [6]. Indeed, better milk efficiency in the treated heifers in the present study indicates the importance of age in relation with infection and its resolution.

Repeated and increasing oronasal doses of LPS showed a tendency for increased ECM with a particular influence at week 3 postpartum in primiparous cows. In another study, ECM increased from $25.0 \mathrm{~kg} / \mathrm{d}$ in control cows fed barley grain-based diets to $27.4 \mathrm{~kg} / \mathrm{d}$ in cows fed a similar diet processed with lactic acid and heat, which lowered rumen LPS content [32]. In support of this hypothesis are other studies that show that primiparous cows cope better with LPS and $E$. coli challenges as evidenced from more moderate inflammatory responses compared with multiparous cows [33-35]. It is postulated that the LPS-treated primiparous cows in our study were probably more efficient in clearance of bacteria and their toxins from mammary gland, which resulted in better milk production outcomes. However, more research is warr anted to prove these assumptions.

Data revealed a tendency for milk lactose and total solid contents to be greater in the treated primiparous cows and this effect was more pronounced immediately after parturition. The precise mechanism by which this variable is higher in the treated primiparous cows is not clear at present. A number of studies have shown decreased milk lactose and casein during LPS-induced inflammation [36], by interfering with cellular secretion of specific milk components [37-39]. Our data are in line with those of Werner-Misof et al. [40] who reported decreased milk lactose content when LPS was infused intramammary between 12.5 to $100 \mu \mathrm{g}$. It was demonstrated that LPS damaged the tight junctions leading to increased permeability of the mammary gland epithelium and leakage of milk lactose in dairy cows. The release of proinflammatory cytokines, following endotoxin challenge, might be another potential reason for necrosis and severe vascular leakage as well as alterations in milk components in dairy cows [1].

\section{CONCLUSION}

In conclusion, repeated oronasal administration of LPS from E. coli 0111:B4 modulated milk composition and SCC in periparturient dairy cows. Overall analysis demonstrated that cows challenged oronasally with LPS had a tendency for lower milk SCC. The parity class had an effect for better milk energy, milk efficiency, milk-fat content, FCM, ECM, lactose content, and total solid contents in the primiparous treated group. More research is warranted to study the mechanism(s) by which LPS affected SCC and milk composition and the reason(s) why primiparous cows responded better to this treatment compared to multiparous cows.

\section{ACKNOWLEDGEMENTS}

Appreciation is expressed to Alberta Milk (Edmonton, Alberta, Canada), Alberta Funding Consortium (Edmonton, Alberta, Canada), and Natural Sciences and Engineering Research Council of Canada (Ottawa, Ontario, Canada) for their financial support. Contributions of S. Pohl, M. Beal, and L. Sanderson in collection of samples from experimental animals is recognized. We also are thankful to the technical staff at the Dairy Research and Technology Center, University of Alberta, for their help and care to the cows.

\section{REFERENCES}

[1] Oliver, S.P. and Calvinho, L.F. (1995) Influence of inflammation on mammary gland metabolism and milk composition. Journal of Animal Science, 73, 18-33.

[2] Zebeli, Q. and Ametaj, B.N. (2009) Relationships between rumen lipopolysaccharide and mediators of inflammatory response with milk fat production and efficiency in dairy cows. Journal of Dairy Science, 92, 3800-3809. doi:10.3168/jds.2009-2178

[3] Wenz, J.R., Barrington, G.M., Garry, F.B., McSweeney, K.D., Dinsmore, R.P., Goodell, G. and Callan, R.J. (2001) Bacteremia associated with naturally occuring acute coliform mastitis in dairy cows. Journal of American Veterinary Medicine Association, 219, 976-981. doi:10.2460/javma.2001.219.976

[4] Ametaj, B.N., Zebeli, Q., Iqbal, S. and Dunn, S.M. (2012) Meeting the challenges of improving health in periparturient dairy cows. WCDS Advances in Dairy Technology, 24, 287-317.

[5] Ametaj, B.N., Zebeli, Q. and Iqbal, S. (2010b) Nutrition, microbiota, and endotoxin-related diseases in dairy cows. Revista Brasileira de Zootecnia, 39, 433-444.

[6] Dong, G., Shimin, S., Wu, Y., Lei, C., Zhou, J. and Zhang, S. (2011) Diet-induced bacterial immunogens in the gastrointestinal tract of dairy cows: Impacts on immunity and metabolism. Acta Veterinaria Scandinavica, 53, 48. doi:10.1186/1751-0147-53-48

[7] Emmanuel, D.G.V., Madsen, K.L., Churchill, T.A., Dunn, S.M. and Ametaj, B.N. (2007) Acidosis and lipopolysaccharide from Escherichia coli B:055 cause hyperpermeability of rumen and colon tissues. Journal of Dairy Science, 90, 5552-5557. doi:10.3168/jds.2007-0257

[8] Pekala, P.H., Kawakami, M., Angus, C.W., Lane, M.D. and Cerami, A. (1983) Selective inhibition of synthesis of enzymes for de novo fatty acid biosynthesis by an endotoxin-induced mediator from exudates cells. Proceed- 
ings of the National Academy of Sciences of the United States of America, 80, 2743-2747.

doi:10.1073/pnas.80.9.2743

[9] Lopez-Soriano, F.J. and Williamson, D.H. (1994) Acute effects of endotoxin (lipopolysaccharide) on tissue lipid metabolism in the lactating rat. The role of delivery of intestinal glucose. Molecular and Cellular Biochemistry, 141, 113-120. doi:10.1007/BF00926174

[10] Khovidhunkit, W., Kim, M.S., Memon, R.A., Shigenaga, J.K., Moser, A.H., Feingold, K.R. and Grunfeld, C. (2004) Effects of infection and inflammation on lipid and lipoprotein metabolism: Mechanisms and consequences to the host. Journal of Lipid Research, 45, 1169-1196. doi:10.1194/jlr.R300019-JLR200

[11] Shuster, D.E., Harmon, R.J., Jackson, J.A. and Hemken, R.W. (1991) Suppression of milk production during endotoxin-induced mastitis. Journal of Dairy Science, 74, 3763-3774. doi:10.3168/jds.S0022-0302(91)78568-8

[12] McFadden, T.B., Akers, R.M. and Capuco, A.V. (1988) Relationship of milk proteins in blood with somatic cell counts in milk of dairy cows. Journal of Dairy Science, 71, 826-834. doi:10.3168/jds.S0022-0302(88)79623-X

[13] Hogan, J.S., Weiss, W.P., Todhunter, D.A., Smith, K.L. and Schoenberger, P.S. (1992) Efficacy of an Escherichia coli $\mathrm{J} 5$ mastitis vaccine in an experimental challenge trial. Journal of Dairy Science, 75, 415-422. doi:10.3168/jds.S0022-0302(92)77777-7

[14] Neutra, M.R. and Kozlowski, P.A. (2006) Mucosal vaccines: The promise and the challenge. Nature Reviews Immunology, 6, 148-158. doi:10.1038/nri1777

[15] Lohuis, J.A.C.M., Schukken, Y.H., Verheijden, J.H.M., Brand, A. and Van Miert, A. (1990) Effect of severity of systemic signs during the acute phase of experimentally induced Escherichia coli mastitis on milk production losses. Journal of Dairy Science, 73, 333-341. doi:10.3168/jds.S0022-0302(90)78678-X

[16] Schmitz, S., Pfaffl, M.W., Meyer, H.H.D. and Bruckmaier, R.M. (2004) Short-term changes of mRNA expression of various inflammatory factors and milk proteins in mammary tissue during LPS induced mastitis. Domestic Animal Endocrinology, 26, 111-126. doi:10.1016/j.domaniend.2003.09.003

[17] Beutler, B. and Rietschel, E.T. (2003) Innate immune sensing and its roots: The story of endotoxin. Nature Reviews Immunology, 3, 169-176. doi:10.1038/nri1004

[18] Petzl, Suojala, L., Orro, T., Järvinen, H., Saatsi, J. and Pyörälä, S. (2008) Acute phase response in two consecutive experimentally induced $E$. coli intramammary infection in dairy cows. Acta Veterinaria Scandinavica, 50, 18. doi:10.1186/1751-0147-50-18

[19] Shuster, D.E. and Harmon, R.J. (1991) Lactating cows become partially refractory to frequent intra-mammary endotoxin infusions: Recovery of milk yield despite a persistently high somatic cell count. Research in Veterinary Science, 51, 272-277. doi:10.1016/0034-5288(91)90077-2

[20] Ametaj, B.N., Sivaraman, S., Dunn, S.M. and Zebeli, Q. (2012) Repeated oral administration of lipopolysaccharide from Escherichia coli 0111:B4 modulated humoral immune responses in periparturient dairy cows. Innate Immunity, 18, 638-647. doi:10.1177/1753425911434851

[21] Canadian Council on Animal Care (1993) Guide to the care and use of experimental animals. 2nd Edition, CCAC, Ottawa.

[22] NRC (2001) Nutrient requirements of dairy cattle. 7th Edition, National Academies Press, Washington DC, 381.

[23] Hill, A.W. (1981) Factors influencing the outcome of Escherichia coli mastitis in the dairy cow. Research in Veterinary Science, 31, 107-112.

[24] Guidry, A.J., Ost, M., Mather, I.H., Shainline, W.E. and Weinland, B.T. (1983) Sequential response of milk leukocytes, albumin, immunoglobulins, monovalent ions, citrate, and lactose in cows given infusions of Escherichia coli endotoxin into the mammary gland. American Journal of Veterinary Research, 44, 2262-2267.

[25] Erskine, R.J., Eberhart, R.J., Grasso, P.J. and Scholz, R.W. (1989) Induction of Escherichia coli mastitis in cows fed selenium-deficient or selenium-supplemented diets. American Journal of Veterinary Research, 50, 2093-2100.

[26] Carroll, E.J., Schalm, O.W. and Lasmanis, J. (1964) Experimental coliform (Aerobacter aerogenes) mastitis: Characteristics of the endotoxin and its role in pathogenesis. American Journal of Veterinary Research, 25, 720-726.

[27] Lengemann, F.W. and Pitzrick, M. (1986) Effects of endotoxin on mammary secretion of lactating cows. Journal of Dairy Science, 69, 1250-1258. doi:10.3168/jds.S0022-0302(86)80531-8

[28] Mattila, T. and Frost, A.J. (1989) Induction by endotoxin of the inflammatory response in the lactating and dry bovine mammary gland. Research in Veterinary Science, 46, $238-240$

[29] Lehtolainen, T., Suominen, S., Kutila, T. and Pyörälä, S. (2003) Effect of intramammary Escherichia coli endotoxin in early- vs. late-lactating dairy cows. Journal of Dairy Science, 86, 2327-2333. doi:10.3168/jds.S0022-0302(03)73825-9

[30] Morimoto, K., Kanda, N., Shinde, S. and Isobe, N. (2012) Effect of enterotoxigenic Escherichia coli vaccine on innate immune function of bovine mammary gland infused with lipopolysaccharide. Journal of Dairy Science, 95, 5067-5074. doi:10.3168/jds.2012-5498

[31] Sweet, M.J. and Hume, D.A. (1996) Endotoxin signal transduction in macrophages. Journal of Leukocyte Biology, 60, 8-26.

[32] Iqbal, S., Terrill, S.J., Zebeli, Q., Mazzolari, A., Dunn, S.M., Yang, W.Z. and Ametaj, B.N. (2012) Treating barley grain with lactic acid and heat prevented sub-acute ruminal acidosis and increased milk fat content in dairy cows. Animal Feed Science and Technology, 172, 141149. doi:10.1016/j.anifeedsci.2011.12.024

[33] van Werven, T., Noordhuizen-Stassen, E.N., Daemen, A.J.J.M., Schukken, Y.H., Brand, A. and Burvenich, C. (1997) Preinfection in vitro chemotaxis, phagocytosis, oxidative burst, and expression of CD11/CD18 receptors and their predictive capacity on the outcome of mastitis induced in dairy cows with Escherichia coli. Journal of 
Dairy Science, 80, 67-74. doi:10.3168/jds.S0022-0302(97)75913-7

[34] Hoeben, D., Monfardini, E., Burvenich, C. and Hamann, J. (2000) Treatment of acute Escherichia coli mastitis in cows with enrofloxacin: Effect on clinical signs and chemiluminescence of circulating neutrophils. Journal of Dairy Science, 67, 485-502.

[35] Vangroenweghe, F., Duchateau, L. and Burvenich, C. (2004) Moderate inflammatory reaction during experimental Escherichia coli mastitis in primiparous cows. Journal of Dairy Science, 87, 886-895. doi:10.3168/jds.S0022-0302(04)73233-6

[36] Hammon, Kitchen, B.J. (1981) Review of the progress of dairy science: Bovine mastitis: Milk compositional changes and related diagnostic tests. Journal of Dairy Research, 48, 167-188. doi:10.1017/S0022029900021580

[37] Patton, S. (1978) Milk secretion at the cellular level: A unique approach to the mechanism of exocytosis. Journal of Dairy Science, 61, 643-650. doi:10.3168/jds.S0022-0302(78)94423-5

[38] Oliver, S.P. and Smith, K.L. (1982) Milk yield and secretion composition following intramammary infusion of colchicine. Journal of Dairy Science, 65, 204-210. doi:10.3168/jds.S0022-0302(82)82178-4

[39] Sordillo, L.M., Oliver, S.P. and Nickerson, S.C. (1984) Caprine mammary differentiation and initiation of lactation following prepartum colchicine infusion. International Journal of Biochemistry, 161, 1265-1272. doi:10.1016/0020-711X(84)90226-X

[40] Werner-Misof, C., Macuhova, J., Tancin, V. and Bruckmaier, R.M. (2007) Dose dependent changes in inflammatory parameters in the milk of dairy cows after intramammary infusion of lipopolysaccharide. Veterinarni Medicina, 523, 95-102. 